\title{
Applied Artificial Intelligence - Making AI Work for Consumers as a Core Business \\ Component
}

\author{
Mikael Wiberg, $\mathrm{PhD}$., Professor \\ Department of Informatics, Umeå University, 901887 Umeå, \\ Sweden \\ mikael.wiberg@umu.se \\ $+46(0) 70662$ 10 70
}

\section{Abstract}

Artificial Intelligence (AI) is now rapidly being applied in our society. While the breakthrough of $\mathrm{AI}$ in terms of its use and its applicability on a societal level has in fact been repeatedly announced since the mid I950s, is now truer than ever. As recently acknowledged, AI has now, after three waves of developments, finally left the research labs and entered realworld contexts. Accordingly, and as AI is now increasingly and widely applied, we suggest that it is now time to address issues related to "Applied Artificial Intelligence" (AAI). In this paper we propose this term, and we define it as the study, design, development, implementation and use of Artificial Intelligence technologies to address real-world problems. In this article we present how AI has developed over the past few decades, and across three waves of developments, and we illustrated Applied Artificial Intelligence by presenting our e-Biz corp case where a global actor is now using $\mathrm{AI}$ as a core component of their online business. We conclude this article with a set of recommendations for moving forward with Applied Artificial 
Intelligence, and we present the main contributions offered by our work to the growing body of research on how to make use of AI.

Keywords: AI, Artificial Intelligence, Applied Artificial Intelligence, Core business

\section{The Breakthrough of Artificial Intelligence in Society}

"Artificial Intelligence is no longer an academic term, but a reality". This could have been said today, given the current and escalating hype surrounding AI. However, it was actually stated by Holloway and Hand (I988) in their Business horizon article published almost 30 years ago. Nevertheless, this statement concerning the large-scale and real-world breakthrough of AI could have also been made today, in the year 2020. In looking back from a historical viewpoint, the proof-of-concept in terms of the wide scale societal breakthrough of Artificial Intelligence (AI) has been a continuously repeated promise and message surrounding the development of this technology over the last few decades, from the mid I950s until today(see e.g. Turing, 1950; Weizenbaum, I966 and Makridakis, S. (20I7).As formulated by $\mathrm{Xu}$ (20I9), we are now already in the $3^{\text {rd }}$ wave of $\mathrm{AI}$, and the promise of $\mathrm{AI}$ has been repeated for each of these three waves of developments of AI technologies.

Still, this statement about the breakthrough of $\mathrm{AI}$ as formulated by Holloway and Hand (1988) might now be truer than ever. As pinpointed by $\mathrm{Xu}$ (2019) this $3^{\text {rd }}$ wave of AI is now characterized by technological enhancements and the deployment and use of AI solutions in society, whereas 
This is a limited preview of the chapter.

To read the full-text chapter, get access by purchasing this chapter or consider buying the complete book. If your library has subscription to EBSCOhost, the chapter including other chapters of the book can be accessed through your library.

This chapter is a part of the book, 'Management of Data in AI Age' ISBN (paperback): 978-8I-948483-4־9; ISBN (ebook): 978-8I$948483-5-6$

Book DOI: https://dx.doi.org/Io.46679/isbn9788194848349 Chapter DOI: https://dx.doi.org/Io.46679/isbn978819484834902 
Finally, and in adding to Xu's (2019) definition of useful AI as "an $A I$ solution that can provide the functions required to satisfy target users' needs in the valid usage scenarios of their work and life" we would like to expand on this notion of "Useful AI", and suggest that it needs to work, not only for users/consumers, but also for the businesses providing the service. In order to successfully apply AI to real-world problems it needs to work, for its users, and for those who provide digital services based on applied artificial intelligence.

\section{References}

[1]. Borgmann, A. (1984) Technology and the character of contemporary life - a philosophical inquiry. The University of Chicago Press.

[2]. Clark, A. (2003) Natural-Born Cyborgs - Minds, Technologies, and the Future of Human Intelligence, Oxford University Press.

[3]. Dignum, V. (2019) Responsible Artificial Intelligence - How to develop and use $\mathrm{AI}$ in a responsible way, Springer.

[4]. Finn, E. (20I7) What algorithms want - Imagination in the age of computing, MIT Press.

[5]. Gilio A. (1995) Algorithms for Precise and Imprecise Conditional Probability Assessments. In: Coletti G., Dubois D., Scozzafava R. (eds) Mathematical Models for Handling Partial Knowledge in Artificial Intelligence. Springer, Boston, MA

[6]. Gomes, C., Fern, X., Fink, D., Fisher, D., Flecker, A., Freund, D., Fern, A. (20I9). Computational sustainability: Computing for a better World and a sustainable future. Communications of the ACM, 62(9), 56-65.

[7]. Gomez-Uribe, CA and Hunt, N. (2016). The Netflix

Recommender System: Algorithms, Business Value, and Innovation. ACM Trans. Manage. Inf. Syst. 6, 4, Article I3 (December 20I6), I9 pages. DOI:https://doi.org/Io.II45/2843948 
[8]. Holloway, C., छə Hand, H. H. (I988). Who's running the store, anyway? Artificial intelligence!!!, Business Horizons, 3I(2), 7076.

[9]. Johnson, Mark छ Christensen, C.C. छ Kagermann, Henning. (2008). Reinventing Your Business Model. Harvard Business Review. 87. 52-60.

[10]. Kaplan, A. M., छ Haenlein, M. (20I9). Siri, Siri, in my hand: Who's the fairest in the land? On the interpretations, illustrations, and implications of artificial intelligence. Business Horizons, 62(I), I5e25.

[11]. Kaplan, A., Haenlein, M. (2020) Rulers of the world, unite! The challenges and opportunities of artificial intelligence, Business Horizons, Volume 63, Issue I,Pages 37־50.

[12]. McCarthy, J., Minsky, M. L., Rochester, N., छ Shannon, C. E. (I955). A proposal for the Dartmouth summer research project on artificial intelligence. Available at http:// www, formal.stanford.edu/jmc/history/dartmouth/ dartmouth.html

[13]. Makridakis, S. (20I7). The forthcoming Artificial Intelligence (AI) revolution: Its impact on society and firms. Futures, IOo(90), 46-6o.

[14]. Miller, A. (2019) The Artist in the Machine - The World of AI-powered creativity, MIT Press.

[15]. Melville, Nigel छ Kraemer, Kenneth छ Gurbaxani, Vijay. (2004). Review: Information Technology and Organizational Performance: An Integrative Model of IT Business Value. MIS Quarterly. 28. 283-322. 10.2307/25I48636.

[16]. Newell, A., and Simon, H. (I972) Human Problem Solving, NJ: Prentice Hall.

[17]. Rahwan, I., Cebrian, M., Obradovich, N. et al. (2019) Machine behaviour. Nature 568, 477-486. https://doi.org/Io.Io38/s4I586, ol9-II38-y

[18]. Stolterman, E. छə Wiberg, M. (2020) Compositional interaction design - changes in design practice and its implications for teaching and research, Digital Creativity, I-20, Routledge.

[19]. Strassmann, PA (I990) The business value of computers, Information Economics Pr. 
[20]. Turing, Alan (October 1950), "Computing Machinery and Intelligence", Mind, LIX (236): 433-460, doi:Io.Io93/mind/LIX.236.433, ISSN $0026 / 4423$

[21]. Turing, Alan (1952), "Can Automatic Calculating Machines be Said to Think?", in Copeland, B. Jack (ed.), The Essential Turing: The ideas that gave birth to the computer age, Oxford: Oxford University Press, ISBN 978-0-19-825080-7

[22]. Van de Ven, A. H., Engaged Scholarship: A Guide for Organizational and Social Research, Oxford University Press, Oxford, 2007.

[23]. Vardouli T., छ Touloumi, O. (2019) Computer Architectures: Constructing the Common Ground, Routledge Research in Design, Technology and Society, Routledge.

[24]. Wei, Xu (2019) Toward human-centered AI, interactions 26(4):42-46, DOI: IO.II $45 / 3328485$

[25]. Weizenbaum, Joseph (January 1966), "ELIZA - A Computer Program For the Study of Natural Language Communication Between Man And Machine", Communications of the ACM, 9 (I): 36-45, doi:Io.II45/365153.365168

[26]. Zook, C., \& Allen, J. (2003). Growth outside the core. Harvard business review, 8I I2, 66-73, I25.

[27]. Zook C. (2007) Finding your next core business. Harvard Business Review. Apr;85(4):66-75, I40.

[29]. Ågerfalk, P. (2020) Artificial intelligence as digital agency, European Journal of Information Systems, 29:I, I-8, DOI: I0.1080/0960085X.2020.1721947 